\title{
MINERAL CONTENT OF MELON FRUIT (CUCUMIS MELO L.)
}

\author{
Joanna Majkowska-Gadomska \\ Chair of Horticulture \\ University of Warmia and Mazury in Olsztyn
}

\begin{abstract}
Melons are highly demanding, thermophilous plants, which is why they are unpopular among fruit growers. Melon cultivation requires special treatment methods for the improvement of microclimatic conditions. Seven Polish melon cultivars are presently grown on the domestic market. They are well adapted to the local climate. The growth rate, vigor, fruit shape, fruit size, rind color and flesh thickness of those cultivars vary. The objective of this study was to determine the mineral content of edible parts of four field-grown melon cultivars in the Warmia region (NE Poland). This study discusses the mineral content of melon fruit subject to the investigated cultivar and cultivation method. In Poland, melon production is difficult and unreliable. The main problem is the selection of an appropriate cultivar and cultivation method. The analyzed material consisted of four Polish melon cultivars: Malaga $F_{1}$, Melba, Oliwin, Seledyn $F_{1}$, grown in a field experiment without protective cover, under polyethylene $(\mathrm{PE})$ sheet cover, under non-woven polypropylene (PP) cover, with soil mulching, as well as with soil mulching under PE sheet cover or nonwoven PP cover. The highest concentrations of total $\mathrm{N}, \mathrm{K}, \mathrm{Ca}$ and $\mathrm{Cu}$ were determined in melon fruit of cv. Oliwin. Significant variations in total nitrogen and phosphorus levels in the edible parts of melon plants were noted subject to the applied cultivation method. $\mathrm{Cu}$ cumis melo L. grown in the control treatment without protective cover was marked by significantly higher levels of total nitrogen and phosphorus in the fruit, compared with fruit grown with the use of other cultivation methods. The results of this study indicate that the fruit of melon plants cv. Seledyn grown in mulched soil under non-woven PP cover was characterized by the most favorable $\mathrm{Ca}: \mathrm{Mg}$ and $\mathrm{Ca}: \mathrm{P}$ ratios in comparison with fruit from the remaining treatments.
\end{abstract}

Key words: melon, cultivars, cultivation methods, chemical composition.

Joanna Majkowska-Gadomska, PhD, Chair of Horticulture, University of Warmia and Mazury in Olsztyn, ul Prawocheńskiego 21, 10-957 Olsztyn, Poland, e-mail: Majkowska-Gadomska@uwm.edu.pl 


\title{
ZAWARTOŚĆ SKŁADNIKÓW MINERALNYCH W OWOCACH MELONA (CUCUMIS MELO L.)
}

\begin{abstract}
Abstrakt
Melon jest rośliną mało rozpowszechniona $\mathrm{w}$ uprawie. Należy do grupy warzyw ciepłolubnym o dużych wymaganiach środowiskowych, $\mathrm{z}$ tego względu $\mathrm{w}$ jego produkcji niezbędne sa zabiegi poprawiające warunki mikroklimatyczne. Obecnie w uprawie znajduje się siedem odmian polskiej hodowli, dobrze przystosowanych do uprawy $\mathrm{w}$ naszych warunkach klimatycznych. Odmiany te charakteryzują się zróżnicowaną siłą wzrostu, kształtem owoców, ich wielkościa, zabarwieniem skórki oraz warstwą miąższu. Celem badań była ocena zawartości składników mineralnych w częściach jadalnych czterech odmian melona uprawianego $\mathrm{w}$ warunkach polowych Warmii, w zależności od badanej odmiany oraz metody uprawy. Uprawa melona w Polsce jest trudna i zawodna. Problem stanowi dobór odpowiedniej odmiany oraz metody jej uprawy. Do badań wytypowano cztery polskie odmiany melona: Malaga $\mathrm{F}_{1}$, Melba, Oliwin, Seledyn $\mathrm{F}_{1}$, uprawianego w polu bez osłon, z zastosowaniem osłaniania roślin folią PE, włókniną PP, mulczowania gleby oraz jednoczesnego mulczowania gleby i osłaniania roślin folią PE lub włóknina PP. Spośród analizowanych odmian istotnie największą zasobnością w $\mathrm{N}$-ogółem, $\mathrm{K}$ oraz $\mathrm{Ca}$ i $\mathrm{Cu}$ charakteryzowały się owoce odmiany Oliwin. Zastosowane $\mathrm{w}$ uprawie melona metody uprawy spowodowały istotne zróżnicowane zawartości azotu ogółem i fosforu w jego częściach jadalnych. Uprawa Cucumis melo L. w obiekcie kontrolnym (bez zastosowania osłon) spowodowała istotne zwiększenie zawartości azotu ogółem i fosforu w porównaniu z innymi analizowanymi metodami uprawy. Analizując stosunki Ca:Mg i Ca:P stwierdzono, że uprawiane na glebie mulczowanej i osłanianej włókniną PP owoce odmiany Seledyn charakteryzowały się korzystna proporcja $\mathrm{Ca}: \mathrm{Mg}$ oraz $\mathrm{Ca}: \mathrm{P}$ w odniesieniu do pozostałych obiektów uprawy.
\end{abstract}

Słowa kluczowe: melon, odmiany, metody uprawy, skład chemiczny.

\section{INTRODUCTION}

Melon fruit enjoys widespread popularity among consumers owing to its taste and high nutritional value. However, melons are highly demanding, thermophilous plants, which makes them relatively unpopular among fruit growers. Melon cultivation requires special treatment methods for the improvement of microclimatic conditions. A number of research studies investigating melon production technologies in various regions of Poland have been initiated to investigate the effect of perforated PE sheet cover, nonwoven PP cover and soil mulching with organic and mineral material on the melon growing process. The applied cultivation measures inhibit weed infestation and improve the microclimatic environment around plants (ŁотоскА, Gajc 1987, Grudzié́ 1992, Libik, Siwek 1994, Siwek 1996, Grudzień 1998, GRUDZIEŃ 2000).

Seven Polish melon cultivars are presently grown on the domestic market. They are well adapted to the local climate. The growth rate, vigor, fruit shape, fruit size, rind color and flesh thickness of those cultivars vary (List of vegetable cultivars entered into the Polish national register 2008). 
The objective of this study was to determine the mineral content of the edible parts of four field-grown melon cultivars in the Warmia region (NE Poland).

\section{MATERIALS AND METHODS}

A two-factorial field experiment was carried out in a split-plot design, in three replications, during the years 2004-2007, at the Experimental Station of the University of Warmia and Mazury in Olsztyn. The first experimental factor were four melon cultivars: Malaga $\mathrm{F}_{1}$, Melba, Oliwin and Seledyn $\mathrm{F}_{1}$. The second factor were the following cultivation methods:

- melon plants grown in the control treatment;

- melon plants grown under perforated polyethylene (PE) sheet cover, 100 openings per $\mathrm{m}^{2}$;

- melon plants grown under non-woven polypropylene (PP) cover, $17 \mathrm{~g} \cdot \mathrm{m}^{-2}$;

- plants grown in soil mulched with black PE sheet;

- melon plants grown in soil mulched with black PE sheet, under perforated $\mathrm{PE}$ sheet cover, 100 openings per $\mathrm{m}^{2}$;

- melon plants grown in soil mulched with black PE sheet, under non-woven $\mathrm{PP}$ cover, $17 \mathrm{~g} \cdot \mathrm{m}^{-2}$.

A pot experiment was conducted in a heated greenhouse in line with generally observed standards for melon cultivation. Melon seeds were sown on 4 May, two seeds per pot filled with peat with the following chemical composition: $\mathrm{N}^{-\mathrm{NO}_{3}}-100, \mathrm{P}-80, \mathrm{~K}-215, \mathrm{Ca}-1240, \mathrm{Mg}-121 \mathrm{mg} \cdot \mathrm{dm}^{-3}$, $\mathrm{pH}$ of $\mathrm{H}_{2} \mathrm{O}-5.9$ and salt concentration of $1.5 \mathrm{~g} \cdot \mathrm{dm}^{-3}$.

Field treatments were set up on brown soil of quality class IVb, good rye complex, developed from loamy sand on loam with $\mathrm{pH}$ of 6.7 and humus content of $2.8 \%$. The chemical composition of soil was analyzed prior to the planting out of seedlings and the following results were obtained: $\mathrm{N}-\mathrm{NO}_{3}-38$, $\mathrm{P}-127, \mathrm{~K}-90, \mathrm{Ca}-1840, \mathrm{Mg}-194\left(\mathrm{mg} \cdot \mathrm{dm}^{-3}\right)$. Mineral deficiencies were supplemented in accordance with standard requirements for melon plants. Soil was mulched with black PE sheet. Hardened seedlings were planted out in soil treatments on 2 June. The spacing between rows was $1.0 \mathrm{~m}$, and plant spacing in a row was $80 \mathrm{~cm}$.

Directly after planting out in soil treatments, seedlings were covered with perforated PE sheet, thickness of 0.02-0.05 mm, 100 openings per $\mathrm{m}^{2}$. The other type of applied cover was Pegas-Agro 17 white non-woven PP fabric with surface density of $17 \mathrm{~g} \cdot \mathrm{m}^{-2}$. Both types of cover were spread directly on the plants and maintained for the first two weeks after planting.

The required cultivation measures were carried out over the growing period. The chemical protection regime was consistent with the Plant Protection Program (2004-2007). Melon fruit was harvested on ripening. Fifteen 
fruits were sampled from the marketable yield of each treatment for determination of the mineral content of edible melon parts. The harvested fruit was comminuted, dried to constant mass at $65^{\circ} \mathrm{C}$, and ground in an electric mill. The prepared material was forwarded to the Chemical and Agricultural Station in Olsztyn, where it was mineralized and analyzed to determine the content of the following macronutrients and micronutrients: nitrogen (total) by potentiometry, phosphorus - by the vanadium-molybdate method, potassium - by flame photometry, magnesium - by atomic absorption spectrometry (AAS), calcium - by flame photometry, copper and iron - by AAS. The study was carried out under Accreditation Certificate no. AB 277 issued by the Polish Center for Accreditation.

The results were validated statistically by analysis of variance. The significance of differences between means was evaluated by constructing Tukey's confidence intervals at $\alpha=0.05$.

\section{RESULTS AND DISCUSSION}

Melon fruit is enjoying growing popularity among consumers owing to its taste as well as high nutritional value. Melon imports are low due to high cost and the fruit's short shelf-life (Grudzień 2000). In Poland, melon production is difficult and unreliable. The main problem is the selection of an appropriate cultivar and cultivation method.

The flesh of ripe melons has a high content of organic and mineral nutrients, which varies subject to cultivar and cultivation method (OuzounIDOU et al. 2006). The results of the study carried out in 2004-2007 show that the levels of the investigated macronutrients (Table 1) were significantly affected by the cultivar, the applied cultivation method and the interactions between these experimental factors.

Nitrogen is one of the most important elements in human diet. The highest levels of this macronutrient were found in melon fruit of cv. Oliwin at $1.49 \mathrm{~g} \cdot \mathrm{kg}^{-1} \mathrm{~d} . \mathrm{m}$., while the lowest $\mathrm{N}$ concentrations were determined in Malaga $F_{1}$ at $1.11 \mathrm{~g} \cdot \mathrm{kg}^{-1} \mathrm{~d} . \mathrm{m}$. The applied cultivation method also affected total $\mathrm{N}$ concentrations in edible parts of melon plants. A significant increase in total nitrogen content was noted in the control treatment. Nitrogen levels in the fruit of melon plants grown in soil mulched with black PE sheet and under non-woven PP cover were low. Nitrogen concentrations in edible parts of melon plants were also significantly affected by the interactions between the above experimental factors. The highest quantities of total nitrogen were accumulated by melon fruit of cv. Oliwin covered with PE sheet. The growing of melon plants of cv. Melba in mulched soil under non-woven $\mathrm{PP}$ cover produced the opposite effect and lowered total $\mathrm{N}$ concentrations in the fruit by $1.3 \mathrm{~g} \cdot \mathrm{kg}^{-1} \mathrm{~d} . \mathrm{m}$. 
Table 1

Total N, P, K, Mg and Ca concentrations in melon fruit (mean values for 2004-2007)

\begin{tabular}{|c|c|c|c|c|c|c|}
\hline \multirow{2}{*}{ Cultivar } & \multirow{2}{*}{ Cultivation method } & \multicolumn{5}{|c|}{ Nutrient (g. $\mathrm{kg}^{-1}$ d.m.) } \\
\hline & & $\mathrm{N}$ & $\mathrm{P}$ & $\mathrm{K}$ & $\mathrm{Mg}$ & $\mathrm{Ca}$ \\
\hline \multirow[t]{2}{*}{ Malaga $\mathrm{F}_{1}$} & $\begin{array}{l}\text { control - no cover } \\
\text { PE sheet } \\
\text { non-woven PP cover } \\
\text { mulch } \\
\text { mulch + PE sheet } \\
\text { mulch + non-woven } \\
\text { PP cover }\end{array}$ & $\begin{array}{l}1.42 \\
1.09 \\
0.98 \\
0.98 \\
1.33 \\
0.86\end{array}$ & $\begin{array}{l}0.50 \\
0.37 \\
0.47 \\
0.39 \\
0.39 \\
0.36\end{array}$ & $\begin{array}{l}4.22 \\
4.10 \\
4.28 \\
4.18 \\
5.21 \\
4.28\end{array}$ & $\begin{array}{l}0.23 \\
0.20 \\
0.21 \\
0.22 \\
0.26 \\
0.25\end{array}$ & $\begin{array}{l}0.39 \\
0.34 \\
0.39 \\
0.34 \\
0.31 \\
0.38\end{array}$ \\
\hline & mean values & 1.11 & 0.41 & 4.38 & 0.23 & 0.36 \\
\hline \multirow[t]{2}{*}{ Melba } & $\begin{array}{l}\text { control - no cover } \\
\text { PE sheet } \\
\text { non-woven PP cover } \\
\text { mulch } \\
\text { mulch + PE sheet } \\
\text { mulch + non-woven } \\
\text { PP cover }\end{array}$ & $\begin{array}{l}1.51 \\
1.09 \\
1.24 \\
1.62 \\
1.04 \\
0.65\end{array}$ & $\begin{array}{l}0.44 \\
0.35 \\
0.49 \\
0.67 \\
0.39 \\
0.41\end{array}$ & $\begin{array}{l}4.00 \\
4.28 \\
4.85 \\
5.41 \\
3.88 \\
3.47\end{array}$ & $\begin{array}{l}0.25 \\
0.31 \\
0.30 \\
0.31 \\
0.22 \\
0.24\end{array}$ & $\begin{array}{l}0.33 \\
0.46 \\
0.60 \\
0.92 \\
0.37 \\
0.47\end{array}$ \\
\hline & mean values & 1.19 & 0.53 & 4.32 & 0.22 & 0.53 \\
\hline \multirow[t]{2}{*}{ Oliwin } & $\begin{array}{l}\text { control - no cover } \\
\text { PE sheet } \\
\text { non-woven PP cover } \\
\text { mulch } \\
\text { mulch + PE sheet } \\
\text { mulch + non-woven } \\
\text { PP cover }\end{array}$ & $\begin{array}{l}1.71 \\
1.95 \\
1.83 \\
1.30 \\
0.83 \\
1.33\end{array}$ & $\begin{array}{l}0.67 \\
0.47 \\
0.58 \\
0.35 \\
0.28 \\
0.47\end{array}$ & $\begin{array}{l}5.41 \\
5.34 \\
5.21 \\
4.32 \\
3.34 \\
4.42\end{array}$ & $\begin{array}{l}0.26 \\
0.31 \\
0.31 \\
0.24 \\
0.23 \\
0.23\end{array}$ & $\begin{array}{l}0.65 \\
0.73 \\
0.54 \\
0.55 \\
0.51 \\
0.38\end{array}$ \\
\hline & mean values & 1.49 & 0.47 & 4.67 & 0.26 & 0.56 \\
\hline \multirow[t]{2}{*}{ Seledyn $F_{1}$} & $\begin{array}{l}\text { control - no cover } \\
\text { PE sheet } \\
\text { non-woven PP cover } \\
\text { mulch } \\
\text { mulch + PE sheet } \\
\text { mulch + non-woven } \\
\text { PP cover }\end{array}$ & $\begin{array}{l}1.62 \\
1.39 \\
1.21 \\
0.89 \\
1.18 \\
1.04\end{array}$ & $\begin{array}{l}0.49 \\
0.47 \\
0.46 \\
0.50 \\
0.43 \\
0.35\end{array}$ & $\begin{array}{l}4.05 \\
5.18 \\
3.83 \\
3.52 \\
4.03 \\
3.32\end{array}$ & $\begin{array}{l}0.22 \\
0.28 \\
0.22 \\
0.15 \\
0.24 \\
0.22\end{array}$ & $\begin{array}{l}0.44 \\
0.51 \\
0.29 \\
0.37 \\
0.57 \\
0.66\end{array}$ \\
\hline & mean values & 1.41 & 0.45 & 4.02 & 0.22 & 0.47 \\
\hline Mean values & $\begin{array}{l}\text { control - no cover } \\
\text { PE sheet } \\
\text { non-woven PP cover } \\
\text { mulch } \\
\text { mulch + PE sheet } \\
\text { mulch + non-woven } \\
\text { PP cover }\end{array}$ & $\begin{array}{l}1.56 \\
1.38 \\
1.31 \\
1.20 \\
1.01 \\
0.98\end{array}$ & $\begin{array}{l}0.53 \\
0.41 \\
0.50 \\
0.48 \\
0.38 \\
0.39\end{array}$ & $\begin{array}{l}4.42 \\
4.73 \\
4.54 \\
4.36 \\
4.74 \\
3.87\end{array}$ & $\begin{array}{l}0.24 \\
0.28 \\
0.26 \\
0.23 \\
0.24 \\
0.24\end{array}$ & $\begin{array}{l}0.43 \\
0.51 \\
0.46 \\
0.55 \\
0.44 \\
0.47\end{array}$ \\
\hline \multicolumn{2}{|c|}{$\begin{array}{l}\text { LSD }_{\alpha=0.05} \\
\quad \text { cultivar (a) } \\
\quad \text { cultivation method (b) } \\
\quad \text { interaction (axb) }\end{array}$} & $\begin{array}{l}0.21 \\
0.23 \\
0.18\end{array}$ & $\begin{array}{l}\text { n.s. } \\
0.08 \\
0.12\end{array}$ & $\begin{array}{c}0.53 \\
\text { n.s. } \\
0.96\end{array}$ & $\begin{array}{l}\text { n.s. } \\
\text { n.s. } \\
\text { n.s. }\end{array}$ & $\begin{array}{c}0.10 \\
\text { n.s. } \\
0.12\end{array}$ \\
\hline
\end{tabular}


A well-balanced diet requires optimal phosphorus levels. According to KunACHOWICZ et al. (2006), melon fruit contains $0.29-0.35 \mathrm{~g} \cdot \mathrm{kg}^{-1} \mathrm{~d}$.m. of phosphorus, subject to its dry matter content. Edible parts of the analyzed plants contained from 0.35 to $0.67 \mathrm{~g} \cdot \mathrm{kg}^{-1} \mathrm{~d} . \mathrm{m}$. of this nutrient. Cultivar had no statistically significant effect on phosphorus levels. Phosphorus concentrations were significantly affected by the cultivation method and by the interaction between the cultivation method and cultivar. The highest $\mathrm{P}$ levels were determined in edible parts of control group melons at $0.53 \mathrm{~g} \cdot \mathrm{kg}^{-1} \mathrm{~d} . \mathrm{m}$., while the lowest phosphorus concentrations were found in treatments with mulched soil and non-woven PP cover. Optimal phosphorus content results were noted in fruit of Oliwin plants grown in the control treatment. The highest drop in phosphorus levels in the fruit was reported when melon plants of cv. Oliwin were grown in mulched soil and covered with PE sheet.

Potassium is yet another macronutrient which is very important for the healthy function of the human body. Potassium levels in melon fruit range from 5.41 to $3.32 \mathrm{~g} \cdot \mathrm{kg}^{-1} \mathrm{~d} . \mathrm{m}$. The highest concentrations of this macronutrient were found in melon fruit of $\mathrm{cv}$. Oliwin from the control treatment as well as in fruit of Melba plants grown in mulched soil.

Statistical analysis revealed that the investigated factors had no significant effect on magnesium levels in edible parts of melon plants. Magnesium concentrations were similar in the fruit of all analyzed cultivars, within the range of $0.15-0.31 \mathrm{~g} \cdot \mathrm{kg}^{-1} \mathrm{~d} . \mathrm{m}$.

Calcium is an essential mineral which builds and maintains healthy bones. On average, the analyzed melon fruit contained from 0.92 to $0.31 \mathrm{~g} \cdot \mathrm{kg}^{-1} \mathrm{~d} . \mathrm{m}$. of this nutrient. The highest calcium levels were determined in edible parts of cv. Oliwin plants, while the lowest calcium concentrations were noted in fruit of Malaga $\mathrm{F}_{1}$ plants.

Iron was another element investigated in this study. Fe levels in edible parts of melon plants differed significantly (Figures 1, 2, 3) in the range from 46 to $360 \mathrm{mg} \cdot \mathrm{kg}^{-1} \mathrm{~d} . \mathrm{m}$. The highest accumulation of iron was found

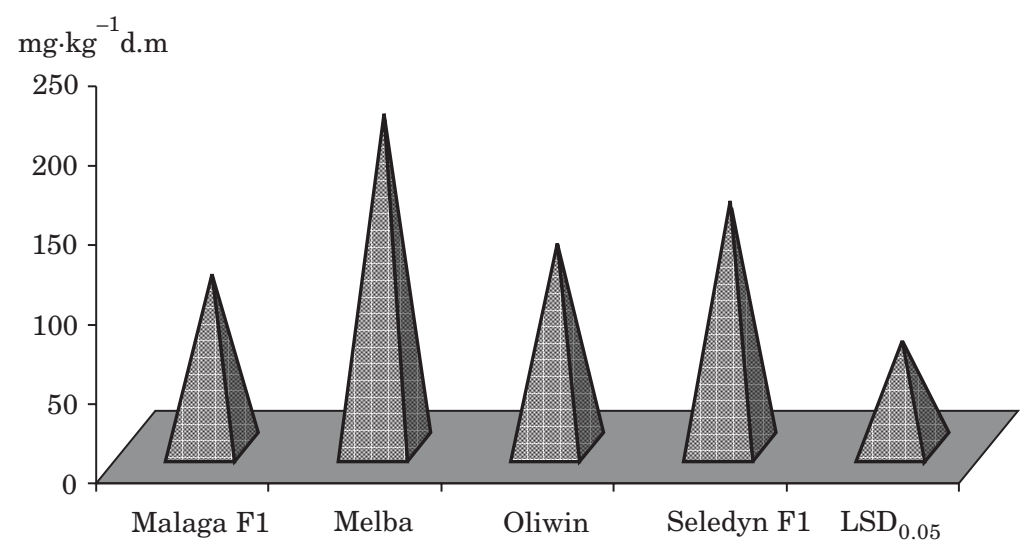

Fig. 1. The effect of cultivar on the iron content of melon fruit (mean values for 2004-2007) 
in fruit of Melba plants covered with PE sheet, while a significant decrease in Fe levels was noted in fruit of melon plants grown in mulched soil under non-woven PP cover.

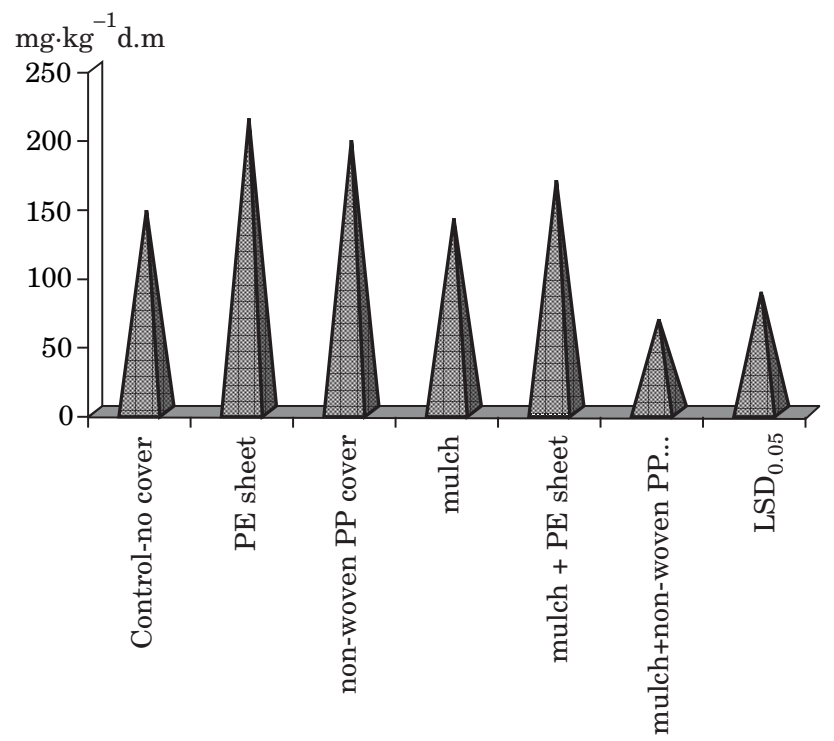

Fig. 2. The effect of cultivation method on the iron content of melon fruit (mean values for 2004-2007)

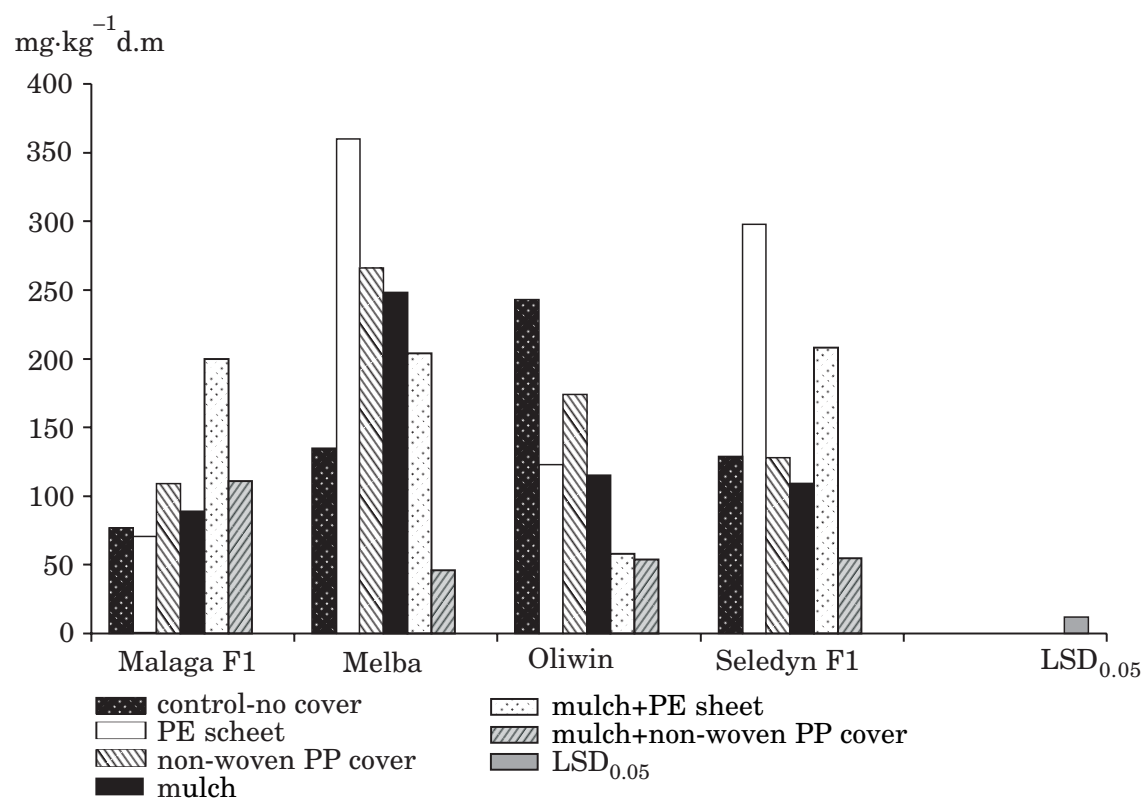

Fig. 3. The effect of interactions between the experimental factors on the iron content of melon fruit (mean values for 2004-2007) 
The edible parts of melon plants were also analyzed to determine copper levels. Copper concentrations were significantly affected by the cultivar and its interactions with the cultivation method (Figures 4, 5). The highest levels of $\mathrm{Cu}$ were accumulated by fruit of Oliwin plants grown in mulched soil.

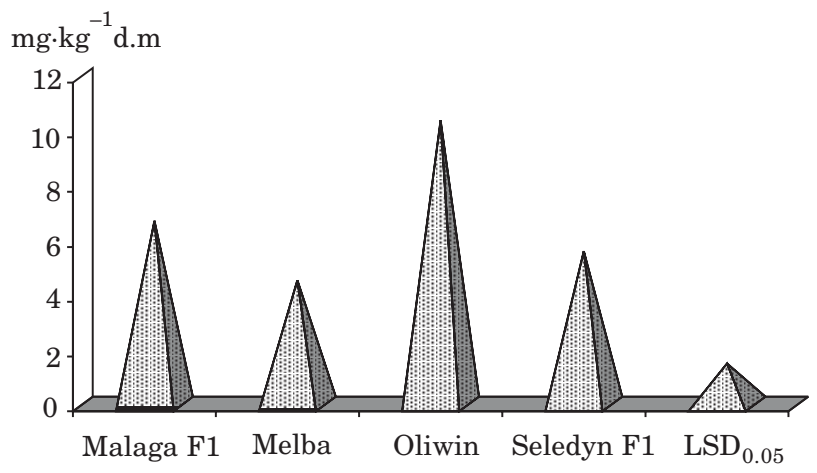

Fig. 4. The effect of cultivar on the copper content of melon fruit (mean values for 2004-2007)

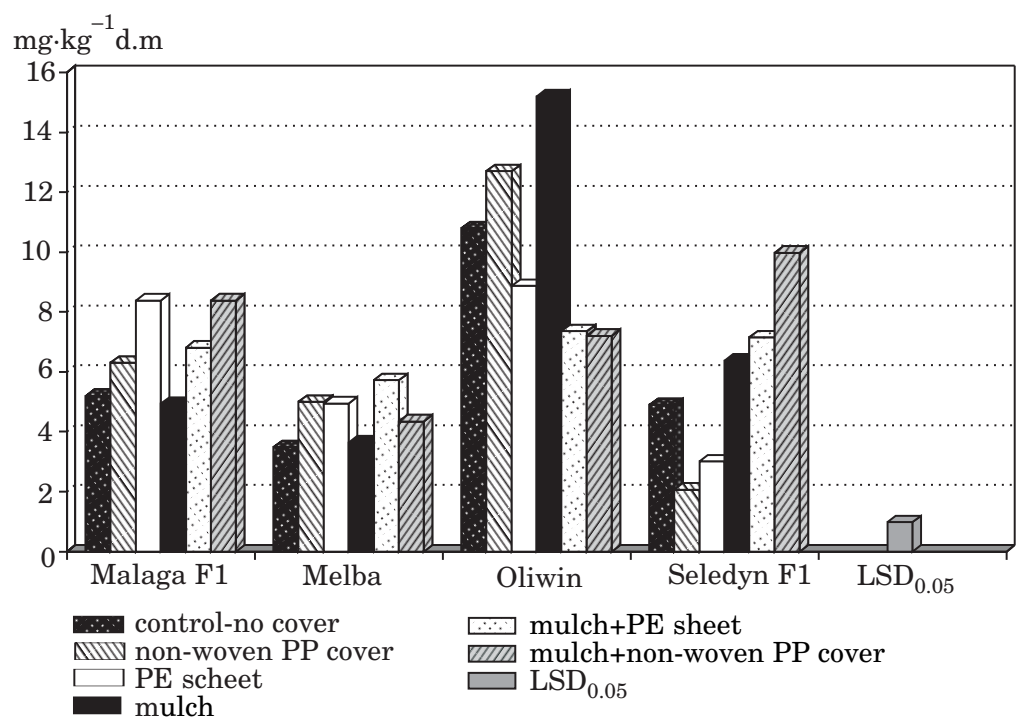

Fig. 5. The effect of interactions between the experimental factors on the copper content of melon fruit

According to Kотоwska and WyBIERALSKI (1999), the quality of plant edible parts is determined by their macronutrient and micronutrient content as well as by nutrient ratios, in particular $\mathrm{K}$ to $\mathrm{Mg}$, $\mathrm{Ca}$ to $\mathrm{Mg}$ and $\mathrm{K}:(\mathrm{Mg}+\mathrm{Ca})$. In the present study, nutrient ratios varied subject to the investigated cultivar and the applied cultivation method (Table 2). 
Table 2

$\mathrm{Ca}: \mathrm{Mg}, \mathrm{Ca}: \mathrm{P}, \mathrm{K}: \mathrm{Mg}$ and $\mathrm{K}:(\mathrm{Mg}+\mathrm{Ca})$ ratios in melon fruit (mean values for 2004-2007)

\begin{tabular}{|c|c|c|c|c|c|}
\hline Cultivar & Cultivation method & $\mathrm{Ca}: \mathrm{Mg}$ & $\mathrm{Ca}: \mathrm{P}$ & $\mathrm{K}: \mathrm{Mg}$ & $\mathrm{K}:(\mathrm{Ca}+\mathrm{Mg})$ \\
\hline \multirow[t]{2}{*}{ Malaga $\mathrm{F}_{1}$} & $\begin{array}{l}\text { control - no cover } \\
\text { PE sheet } \\
\text { non-woven PP cover } \\
\text { mulch } \\
\text { mulch + PE sheet } \\
\text { mulch + non-woven } \\
\text { PP cover }\end{array}$ & $\begin{array}{l}1.87 \\
2.06 \\
2.69 \\
1.55 \\
1.20 \\
1.72\end{array}$ & $\begin{array}{l}0.79 \\
0.92 \\
1.12 \\
0.91 \\
0.80 \\
1.23\end{array}$ & $\begin{array}{l}21.17 \\
20.61 \\
24.42 \\
19.02 \\
20.05 \\
17.14\end{array}$ & $\begin{array}{l}7.12 \\
7.31 \\
6.47 \\
7.47 \\
9.16 \\
6.34\end{array}$ \\
\hline & mean values & 1.85 & 0.96 & 20.40 & 7.31 \\
\hline \multirow[t]{2}{*}{ Melba } & $\begin{array}{l}\text { control - no cover } \\
\text { PE sheet } \\
\text { non-woven PP cover } \\
\text { mulch } \\
\text { mulch + PE sheet } \\
\text { mulch + non-woven } \\
\text { PP cover }\end{array}$ & $\begin{array}{l}1.32 \\
1.60 \\
2.08 \\
2.96 \\
1.69 \\
2.37\end{array}$ & $\begin{array}{l}0.94 \\
0.94 \\
0.91 \\
1.37 \\
0.95 \\
1.15\end{array}$ & $\begin{array}{l}15.80 \\
14.87 \\
17.52 \\
17.47 \\
17.72 \\
16.76\end{array}$ & $\begin{array}{l}6.82 \\
5.61 \\
5.58 \\
4.42 \\
6.58 \\
4.89\end{array}$ \\
\hline & mean values & 2.01 & 1.04 & 16.69 & 5.65 \\
\hline \multirow[t]{2}{*}{ Oliwin } & $\begin{array}{l}\text { control - no cover } \\
\text { PE sheet } \\
\text { non-woven PP cover } \\
\text { mulch } \\
\text { mulch + PE sheet } \\
\text { mulch + non-woven } \\
\text { PP cover }\end{array}$ & $\begin{array}{l}2.79 \\
2.36 \\
1.74 \\
2.29 \\
2.24 \\
1.65\end{array}$ & $\begin{array}{l}0.98 \\
1.55 \\
0.93 \\
1.58 \\
1.83 \\
0.81\end{array}$ & $\begin{array}{l}23.21 \\
17.27 \\
16.81 \\
18.00 \\
14.65 \\
19.24\end{array}$ & $\begin{array}{l}5.60 \\
5.14 \\
6.13 \\
5.48 \\
4.51 \\
7.27\end{array}$ \\
\hline & mean values & 2.18 & 1.28 & 18.20 & 5.75 \\
\hline \multirow[t]{2}{*}{ Seledyn $\mathrm{F}_{1}$} & $\begin{array}{l}\text { control - no cover } \\
\text { PE sheet } \\
\text { non-woven PP cover } \\
\text { mulch } \\
\text { mulch + PE sheet } \\
\text { mulch + non-woven } \\
\text { PP cover }\end{array}$ & $\begin{array}{l}2.03 \\
1.86 \\
1.38 \\
2.48 \\
2.38 \\
3.12\end{array}$ & $\begin{array}{l}0.90 \\
1.09 \\
0.63 \\
0.81 \\
1.94 \\
1.94\end{array}$ & $\begin{array}{l}18.69 \\
19.59 \\
17.06 \\
23.51 \\
16.81 \\
16.23\end{array}$ & $\begin{array}{l}6.14 \\
6.79 \\
7.28 \\
6.78 \\
4.98 \\
3.87\end{array}$ \\
\hline & mean values & 2.21 & 1.22 & 18.65 & 5.97 \\
\hline Mean values & $\begin{array}{l}\text { control - no cover } \\
\text { PE sheet } \\
\text { non-woven PP cover } \\
\text { mulch } \\
\text { mulch + PE sheet } \\
\text { mulch + non-woven } \\
\text { PP cover }\end{array}$ & $\begin{array}{l}2.00 \\
1.97 \\
1.97 \\
2.32 \\
1.88 \\
2.21\end{array}$ & $\begin{array}{l}0.90 \\
1.13 \\
0.90 \\
1.17 \\
1.38 \\
1.28\end{array}$ & $\begin{array}{l}19.72 \\
18.09 \\
18.95 \\
19.50 \\
17.31 \\
17.35\end{array}$ & $\begin{array}{l}6.52 \\
6.21 \\
6.37 \\
6.04 \\
6.31 \\
5.59\end{array}$ \\
\hline \multicolumn{2}{|c|}{$\begin{array}{l}\text { LSD }_{\alpha=0.05} \\
\quad \text { cultivar (a) } \\
\text { cultivation method (b) } \\
\text { interaction (axb) }\end{array}$} & $\begin{array}{c}\mathrm{ns} \\
\mathrm{ns} \\
0.95\end{array}$ & $\begin{array}{c}\mathrm{ns} \\
\mathrm{ns} \\
0.43\end{array}$ & $\begin{array}{l}\mathrm{ns} \\
\mathrm{ns} \\
\mathrm{ns}\end{array}$ & $\begin{array}{c}0.93 \\
\mathrm{~ns} \\
1.91\end{array}$ \\
\hline
\end{tabular}


As demonstrated by RADKOwski et al. (2005), MAJKowsKA-GADOMSKA (2006), MajKowsKa-Gadomska and WierzBicka (2008), the optimal Ca:Mg ratio should approximate 3 , and the $\mathrm{Ca}: \mathrm{P}$ ratio should be within the $1.2-2.2$ range. A higher ratio is indicative of magnesium or phosphorus deficiency. The analyzed melon fruit was marked by a low calcium to magnesium and calcium to phosphorus ratios. The only exception was fruit of Seledyn $F_{1}$ plants grown in mulched soil under non-woven PP cover, where a satisfactory Ca:Mg ratio was noted. Ca:P ratios are a very important consideration in children's nutrition. The optimal Ca:P ratio of 1.94 was observed in fruit of Seledyn $\mathrm{F}_{1}$ plants grown in mulched soil under PE sheet or non-woven PP cover.

All the analyzed cultivars showed a wider potassium to magnesium ratio and a wider potassium to total magnesium and calcium ions ratio. According to RADKOWsKI et al. (2005), the optimal ratios are $\mathrm{K}: \mathrm{Mg}-6: 1$ and $\mathrm{K}:(\mathrm{Mg}+\mathrm{Ca})-1.6-2.2$. The variations in the $\mathrm{K}: \mathrm{Mg}$ ratio in melon fruit were not statistically validated, but a tendency to an increased $\mathrm{K}: \mathrm{Mg}$ ratio was noted in Malaga $\mathrm{F}_{1}$ fruit. The potassium to total magnesium and calcium ions ratio was significantly affected by the cultivar and its interaction with the cultivation method. The widest $\mathrm{K}:(\mathrm{Mg}+\mathrm{Ca})$ ratio was determined in fruit of Malaga $\mathrm{F}_{1}$ plants grown in mulched soil under $\mathrm{PE}$ sheet cover.

\section{CONCLUSIONS}

1. The highest total $\mathrm{N}, \mathrm{K}, \mathrm{Ca}$ and $\mathrm{Cu}$ concentrations were determined in melon fruit of cv. Oliwin.

2. Cucumis melo L. grown in the control treatment without protective cover was marked by significantly higher levels of total nitrogen and phosphorus in the fruit, compared with fruit grown with the use of other cultivation methods.

3. The fruit of melon plants cv. Seledyn $\mathrm{F}_{1}$ grown in mulched soil under non-woven $\mathrm{PP}$ cover showed the optimal $\mathrm{Ca}: \mathrm{Mg}$ and $\mathrm{Ca}: \mathrm{P}$ ratios, in comparison with fruit from the remaining treatments.

\section{REFERENCES}

Grudzień K.1992. Możliwość polowej uprawy kawona w Polsce [Possibility of field cultivation of watermelon]. Ogrodnictwo, 2:18-19. (in Polish)

GRUDZIEŃ K. 1998. Uprawa melonów w świetle doświadczeń skierniewickich [Melon cultivation in the light of experiments conducted in Skierniewice]. Nowości Warzywnicze, 32: 43-44. (in Polish)

Grudzień K. 2000. Możliwość polowej uprawy melona w Polsce [Possibility of field cultivation of melon]. Ogrodnictwo, 5:15-18. (in Polish)

Kotowska J., Wybieralski J. 1999. Ksztattowanie się stosunków ilościowych między $K$, Ca $i \mathrm{Mg} \mathrm{w}$ glebie oraz roślinach [The shaping of quantitative rtios between $K$, Ca and $\mathrm{Mg}$ in soil and in plants]. Biul. Magnezol., 4 (1):104-110. (in Polish) 
Kunachowicz H., Iwanow K., Nadolna I., Przygoda B. 2006. Tabele wartości odżywczej produktów spożywczych [Tables of nutritive value of fod products]. Wyd. Lekarskie, PZWL, Warszawa, pp. 64-65. (in Polish)

LiBiK A, SiweK P. 1994. Changes in soil temperature affected by the aplication of plastic covers in field production of lettuce and vatermelon. Acta Hort., 371:269-274

Lista odmian roślin warzywnych wpisanych do krajowego rejestru Polsce [A list of vegetable plants in the Polish register]. 2008. COBORU, Słupia Wielka. (in Polish)

Łotocka B, GAJC J. 1987. Możliwości upraw melonów w warunkach polowych [Possibilities of growing melons under field conditions]. Ogrodnictwo, 4:13-15. (in Polish)

MAJKowsKa-GadomsKa J. 2006. Effect of sorbents on concentrations of some trace elements in Butter-Head lettuce (Lactuca sativa L. var. Capitata L.). Pol. J. Environ. Stud., 15, (2a): 415-41.

Majkowska-Gadomska J., Wierzbicka B. 2008. Content of basic nutrients and minerals in heads of selected varieties of red cabbage (Brasicca oleracea var. capitata f. rubra). Pol. J. Environ. Stud., 17 (2a): 295-298.

Ouzounidou G., Papadopoulou P., Giannakoula I., Ilias I. 2006. Effect of plant growth regulators on growth physology and quality characteristics of Cucumis melo L. Vegetable Crops Res. Bull., 65: 127-135.

Radkowski A., Grygierzec B., SoŁek-Podwika K. 2005. Zawartość sktadników mineralnych $w$ wybranych gatunkach $i$ odmianach traw [Content of mineral components in some grass species and varieties]. J. Elementol., 10 (1): 121-128. (in Polish)

SiweK P. 1996. Jakość owoców melona $w$ uprawie pod ostonami z tworzyw sztucznych [Quality of melon fruits grown under artificial fabric cover]. Mat. VI Ogólnopol. Zjazdu Hodowców Roślin Ogrodniczych „Hodowla roślin o podwyższonej jakości” Kraków, 388-390. (in Polish) 
